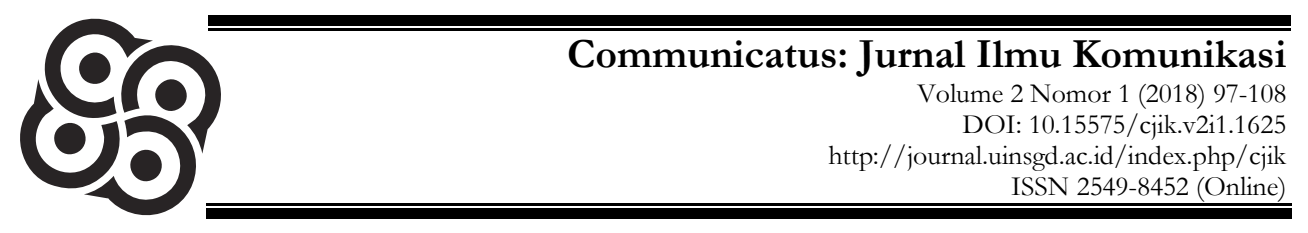

\title{
Hubungan Komunikasi dengan Prestasi Atlet
}

\author{
Fandu Faisal $^{1 *}$, Zulham $^{2}$, Abdul Syukur $^{3}$, Dini Safitri $^{4}$ \\ ${ }^{1234}$ Universitas Negeri Jakarta \\ *email:pandufaisal@unj.ac.id
}

\begin{abstract}
This study aims to explain the relationship of communication with the achievements of badminton athletes SMP 116 Ragunan, on Djarum Sirnas championship, 2017. Many examples of cases, athletes who have not realized that they have more ability in himself, becomes an interesting problem to be examined and whether it has something to do with communication between athlete and coach? Researchers use the theory communication, especially about the factors that influence the formation of communication, to be able to explore the process of interpersonal communication between athletes and trainers. The methodology of this research is quantitative. The results showed that there was a relationship between coach communication, both in verbal and nonverbal communication with athlete achievement. The communication skills of the coach in building or creating shared, open, and shared communication messages of content (athletes with trainers) have a stronger relationship than the other 3 dimensions, namely the dimension of collaboration, the dimension of critical thinking, and the dimensions of creativity.
\end{abstract}

Keywords : communication, coach, athlete, badminton, achievement

\begin{abstract}
ABSTRAK
Penelitian ini bertujuan untuk menjelaskan hubungan komunikasi dengan prestasi atlet bulutangkis SMP 116 Ragunan, pada kejuaran Djarum Sirnas, 2017. Banyak contoh kasus, atlet yang belum menyadari bahwa mereka memiliki kemampuan lebih di dalam dirinya, menjadi masalah menarik untuk diteliti dan apakah hal tersebut ada hubungannya dengan komunikasi antara atlet dengan pelatih? Peneliti menggunakan teori komunikasi, khususnya mengenai faktor-faktor yang mempengaruhi terbentuknya komunikasi, untuk dapat mengeksplorasi proses komunikasi interpersonal antara atlet dan pelatih. Metodologi penelitian ini adalah kuantitatif. Hasil penelitian menunjukan bahwa terdapat hubungan antara komunikasi pelatih, baik dalam komunikasi verbal dan nonverbal dengan prestasi atlet. Kemampuan komunikasi pelatih dalam membangun atau menciptakan pesan-pesan komunikasi (content) yang bersifat berbagi pemikiran, terbuka, dan mencakup solusi untuk kepentingan bersama (atlet dengan pelatih) memiliki hubungan yang lebih kuat dibanding 3 dimensi lainnya, yaitu dimensi collaboration, dimensi critical thinking, dan dimensi creativity.
\end{abstract}

Kata kunci: komunikasi, pelatih, atlet, bulutangkis, prestasi 


\section{PENDAHULUAN}

Penelitian ini berawal dari keresahan peneliti terhadap sejumlah masalah dalam diri para atlet remaja. Peneliti melihat, para atlet remaja terlihat kurang memiliki semangat untuk menata kelak tujuan hidup mereka saat ini. Hal ini dapat dilihat dari beberapa contoh kasus, seperti atlet remaja yang memiliki kemampuan lebih di dalam dirinya, namun jarang yang menyadari potensi tersebut, bahkan ragu untuk mengembangkannya. Peneliti berasumsi, hal tersebut ada hubungannya dengan kondisi usia remaja yang merupakan masa transisi dari anak- anak menuju dewasa awal. Pada tahap ini, biasanya diisi dengan pencarian jati diri dan minat seseorang. Untuk dapat mengatasi hal tersebut, peneliti membuat hipotesis bahwa komunikasi atlet dengan pelatih akan dapat menjadi solusi.

Penelitian ini dilakukan karena penelitian mengenai komunikasi dan olahraga masih jarang untuk diteliti. Padahal, olahraga mendapat perhatian yang cukup besar saat ini, baik untuk meningkatkan kualitas manusia, maupun pencapaian prestasi. Pemerintah juga mendukung dengan memfasilitasi masyarakat dengan disediakannya sekolah khusus atlet. Sekolah atlet diperuntukan sebagai salah satu lingkungan untuk pendidikan yang sangat berperan dalam memupuk bibit-bibit olahragawan yang berpotensial, karena di sekolah inilah mereka dikenalkan dengan dunia gerak dan aktivitas fisik yang terarah.

SMP 116 Ragunan merupakan sekolah binaan pemerintah yang berlokasi di ibu kota dan fokus di bidang olahraga. Test kemampuan dasar dalam berolahraga merupakan syarat untuk lolos ke dalam sekolah tersebut. Oleh karena itu, bagi masyarakat umum yang bercita-cita atau berpotensi menjadi atlet dapat diarahkan untuk mendaftar dan mengikuti seleksi di sekolah tersebut. Karena alasan tersebut, SMP ini dipilih menjadi tempat penelitian. Sementara itu, pemilihan cabang bulutangkis yang menjadi objek penelitian, karena merupakan olahraga yang cukup lama ada di Indonesia, merupakan olahraga populer yang diminati masyarakat Indonesia, dan telah banyak atlet bulutangkis yang menjadi juara di level internasional.

Alasan terakhir merupakan alasan yang paling kuat, yaitu beragam prestasi sudah banyak ditorehkan atlet Indonesia di cabang olahraga bulu tangkis, baik nasional, regional, sampai internasional. Oleh karena itu, dalam upaya menggapai prestasi yang lebih baik, maka pembinaan harus dimulai dari pembinaan sejak dini, terutama pada atlet muda berbakat. Bibit atlet yang unggul perlu pengolahan dan proses kepelatihan secara ilmiah, barulah muncul prestasi atlet semaksimal mungkin, pada umur-umur tertentu. Pada umumnya, atlet berbakat umur muda dapat ditemukan di sekolah-sekolah. Setelah ditemukan, dalam proses bertanding, pelatih yang baik sangat diperlukan, agar tercipta hubungan yang harmonis antara pelatih dan atlet. Hubungan tersebut tidak terbatas pada 
permasalahan teknis dilapangan, tetapi masalah non teknis dan pribadi juga diperhatikan bahkan bila perlu diselesaikan bersama agar tercipta suasana latihan yang benar-benar selaras dengan tujuan yang ingin dicapai.

Penelitian tentang komunikasi atlet dalam berbagai sudut pandang pernah dilakukan sebelumnya, antara lain, penelitian tentang proses komunikasi pelatih dengan atlet panjang tebing (Saputro, 2014). Hasil penelitian menunjukkan bahwa proses komunikasi interpersonal antara pelatih dan atlet dimaknai sebagai ruang untuk saling memotivasi satu sama lain. Penelitian tentang hubungan efektifitas komunikasi interpersonal pelatih dengan ketangguhan mental atlet (Giandra \& Setyawan, 2014). Hasil penelitian menunjukkan bahwa terdapat hubungan signifikan antara komunikasi interpersonal pelatih dengan ketangguhan mental atel. Semakin tinggi intensitas komunikasi interpersonal pelatih maka semakin besar ketangguhan mental atlet. Penelitian lainnya berkaitan dengan hubungan komunikasi interpersonal pelatih dan atlet dengan kecemasan bertanding (Setiani \& Sakti, 2014). Penelitian ini mengambil studi kasus pada atlet PBSI Kota Semarang. Hasil penelitian menunjukkan bahwa kecemasan atlet dengan efektifitas komunikasi pelatih dalam pertandingan tidak memiliki hubungan yang signifikan. Sebab kecemasan sangat dipengaruhi oleh persepsi atlet tentang pertandingan.

Selanjutnya, penelitian tentang efektifitas komunikasi interpersonal pelatih dan atlet bulutangkis dalam meningkatkan prestasi di Dinas Pemuda dan Olahraga propinsi Riau (Charles \& Nurjanah, 2016). Penelitian serupa berkaitan dengan efektifitas komunikasi interpersonal antara ayah dan anak yang berprofeso sebagai atlet Muay Thai dalam menjaga sikap profesionalisme (Torana, 2016) dan penelitian tentang efektifitas komunikasi interpersonal antara pelatih dan atlet panahan dalam meingkatkan prestasi atlet (Oktafiranda, Pelana \& Marani, 2015). Hasil penelitian menunjukkan bahwa sikap profesionalisme di kalangan atlet terjaga melalui proses komunikasi interpersonal di antara pelatih dan atlet sebagai ruang memotivasi dan dukungan. Penelitian tentang komunikasi atlet penyandang cacat (Hafiar, 2012). Penelitian menyimpulkan bahwa komunikasi antar atlet terjadi dan saling mempengaruhi baik pada sisi positif maupun negatif. Penelitian tentang komunikasi intrapersonal dalam kesuksesan anak (Jatmikowati, 2018). Penelitian ini merekam faktor internal dalam perspektif komunikasi yang dapat mendorong prestasi anak.

Seorang pelatih yang baik dalam memainkan perannya harus siap terlibat untuk menyelesaikan masalah-masalah dilapangan, selain itu juga mengembangkan semua potensi yang dimiliki secara maksimal. Salah satu upaya untuk mengenal pribadi atlet dapat dilakukan dengan pemahaman terhadap motivasi atlet. Oleh karena itu, penelitian ini tertarik meneliti lebih lanjut mengenai hubungan upaya peningkatan prestasi dengan komunikasi pelatih dapat mempengaruhi atlet SMP 116 Ragunan saat bertanding. Peneliti 
mengambil sampel pada kejuaraan Djarum Sirnas tahun 2017. Peneliti ingin mencari tahu bagaimana cara pelatih berkomunikasi pelatih kepada atlet, dan hubungannya terhadap prestasi pada cabang olahraga Bulutangkis SMP 116 Ragunan, khususnya pada kejuaraan Djarum Sirnas 2017. Untuk itu penelitian ini memfokuskan pada kajian komunikasi interpersonal antara pelatih dan atlet, khususnya pada hubungan dengan prestasi atlet bulutangkis.

Penelitian ini bertujuan untuk mengetahui hubungan komunikasi dengan prestasi atlet bulutangkis SMP 116 Ragunan melalui pengaruh komunikasi oleh pelatih pada Kejuaraan Djarum Sirnas tahun 2017. Penelitian ini dilaksanakan di SMP 116 Ragunan Jakarta Selatan. Metode penelitian yang digunakan adalah metode survei, dengan teknik perolehan data melalui penyebaran angket untuk data komunikasi dan telaah dokumen untuk data prestasi atlet bulutangkis. Populasi dalam penelitian ini adalah 30 siswa yang mengikuti kepelatihan cabang olahraga bulutangkis di SMP 116 Ragunan. Teknik pengambilan sampel dilakukan dengan total sampling 30 orang siswa cabang olahraga Bulutangkis di SMP 116 Ragunan. Untuk menentukan reliabilitas, peneliti menggunakan rumus Spearman-Brown. Untuk Teknik analisis data, peneliti menggunakan tiga buah teknik, yaitu uji normalitas, uji homogenitas, dan uji keberartian korelasi.

\section{HASIL DAN PEMBAHASAN}

Menurut Bloom dalam Arikunto, prestasi adalah hasil belajar dibedakan menjadi tiga aspek yaitu kognitif, afektif dan psikomotorik. Untuk mendapatkan prestasi olahraga banyak faktor - faktor yang mempengaruhinya, seperti kondisi fisik yang merupakan unsur atau kemampuan dasar yang harus dimiliki setiap atlet untuk meraih suatu prestasi olahraga. Kondisi fisik menggambarkan kemampuan fungsi tubuh seorang atlet, setiap atlet harus menguasai teknik dari cabang olahraga tersebut, dan sesuai dengan kondisi fisiknya. Kondisi fisik dan teknik merupakan unsur yang dibutuhkan untuk menerapkan dan merealisasikan taktik atau strategi pada saat dilapangan dan yang terakhir bagi seorang pelatih dan atlet harus mempunyai mental yang kuat, karena dari mental yang kuat seseorang bisa mengambil keputusan dan tidak terburu-buru.

Semua faktor tersebut tidak akan pernah ada tanpa adanya seorang pelatih. Pelatih dalam dunia olahraga merupakan pemimpin dalam dunia olahraga. Pelatih merupakan fasilitator yang menyelenggarakan program, tempat serta fasilitas latihan bagi atlet yang ingin berprestasi sesuai dengan harapan pelatih. Menurut sukadiyanto (2007: 77), pelatih yang baik memiliki kriteria sebagai berikut, memiliki pengetahuan dan ketrampilan cabang olahraga profesinya, bersikap kepribadian yang baik, sehat jasmani dan rohani. Setiap pelatih memiliki karakteristik yang berbeda-beda tetapi hal wajib yang harus dipahami sebagai pelatih yaitu mengenal atlet secara keseluruhan, bersama atlet mengolah cabang olahraga pilihannya, mengembangkan kepribadian atlet, 
mengajarkan rasa hormat, mengawasi kesehatan atlet, menyadarkan atlet tentang pentingnya berlatih, serta menanamkan kepatuhan kepada atlet dan terencana dengan baik. Yang kedua tipe pelatih yang banyak disenangi dikarenakan pelatih yang fleksibel dan kreatif dalam pendekatan kepada atlet dan penuh perhatian dengan menganggap atlet sebagai individu yang berbeda dalam perlakuannya. Yang ketiga pelatih yang mengurangi keterlibatannya dalam tim. Hal ini tercemin dengan tidak adanya komitmen dalam tim. Pelatih ini terbiasa mempersiapkan diri dan segala sesuatunya tidak terencana, sehingga ia hanya berperan sebagai konsultan.

Dari tipe-tipe pelatih tersebut, semua di dasari pada sifat dasar manusia yang merupakan makhluk sosial. Sebagai makhluk sosial, manusia perlu berkomunikasi dalam kehidupan sehari-hari untuk mendapatkan informasi yang sangat berguna. Setiap manusia melakukan komunikasi, baik komunikasi verbal maupun nonverbal. Istilah komunikasi berasal dari kata Latin communicare atau communis yang berarti sama atau menjadi milik bersama. Menurut Suprapto dalam Mylsidayu (2015:80), komunikasi adalah suatu proses penyampaian pesan berupa lambang, suara, gambar, dan sebagainya dari suatu sumber kepada sasaran (audience) dengan menggunakan saluran tertentu. Proses komunikasi secara spesifik mempelajari atau mengajarkan sesuatu, untuk mempengaruhi perilaku seseorang, mengungkapkan perasaan, menjelaskan perilaku sendiri atau perilaku orang lain, berhubungan dengan orang lain, menyelesaikan sebuah masalah dan menyampaikan sebuah tujuan. Sementara itu, dalam olahraga juga bervariasi, seperti ada kemungkinan untuk mengevaluasi prestasi yang sudah dicapai, untuk menginformasikan kepada siswa untuk melakukan keterampilan baru dalam bermain bulutangkis, dan komunikasi dapat menggabungkan beberapa tujuan sekaligus.

Dennis Murphy dalam Muhammad (2011: 2) mengatakan komunikasi adalah seluruh proses yang dipergunakan untuk mencapai pikiran-pikiran orang lain. Dalam teori tersebut dapat dikatakan bahwa komunikasi yang didapat oleh penerima pesan bertujuan untuk mengetahui pikiran-pikiran yang akan disampaikan oleh pemberi pesan. Selanjutnya Louis Forslade dalam Nurjaman dan Umam (2012:36) mengatakan komunikasi adalah suatu proses memberikan signal menurut aturan tertentu, sehingga dengan cara ini suatu sistem dapat didirikan, dipelihara, dan diubah. Menurut Joseph Dominick (2002), setiap komunikasi akan melibatkan delapan eleman komunikasi, yang meliputi: sumber, enkoding, pesan, saluran, dekoding, penerima, umpan balik, dan gangguan (Yuniarti, 2011).

Menurut Widjaja (2010: 11), penyampaian sebuah pesan komunikasi, tidak hanya melalui pemberi dan penerima pesan tetapi juga mempunyai sebuah proses agar sebuah pesan yang akan disampaikan sesuai dengan apa yang diharapkan. Proses komunikasi pada hakikatnya adalah proses penyampaian 
pikiran atau perasaan oleh seseorang (komunikator) kepada orang lain (komunikan). Pikiran bisa berupa gagasan, informasi, opini, dan lain-lain yang muncul dari benaknya. Komunikator berupa individu yang sedang berbicara, menulis, kelompok orang, organisasi komunikasi seperti surat kabar, radio, televisi, film dan sebagainya. Pesan merupakan keseluruhan daripada apa yang disampaikan oleh komunikator. Saluran komunikasi selalu menyampaikan pesan yang dapat diterima melalui panca indera atau menggunakan media.

Komunikan atau penerima pesan dibagi menjadi 3 yaitu: Komunikasi persona merupakan komunikasi yang ditujukan kepada sasaran yang tunggal, komunikasi kelompok komunikasi yang ditujukan kepada kelompok yang tertentu, dan komunikasi massa merupakan komunikasi yang ditujukan kepada masa atau komunikasi yang menggunakan media massa. Dan hasil akhir dari komunikasi, yakni sikap dan tingkah laku orang, sesuai atau tidak sesuai dengan yang kita inginkan.

Menurut Hardjana (2013: 22), jenis-Jenis komunikasi terbagi menjadi dua. Yang pertama komunikasi verbal dikenal dengan komunikasi yang secara langsung dirasakan oleh pendengar. Secara umum dapat diartikan, komunikasi verbal adalah komunikasi yang menggunakan kata-kata, entah lisan maupun tulisan. Komunikasi ini paling banyak dipakai dalam hubungan antar manusia melalui kata-kata.

Menurut Dadan dan Kresnowati (2008: 12), komunikasi verbal juga merujuk pada proses penyampaian pesan menggunakan kata-kata (bahasa). Bahasa merupakan suatu kegiatan yang sangat esensial untuk menyaitkan diri atau pandangan dunia nyata. Ada beberapa unsur penting dalam komunikasi verbal, yaitu: pada dasarnya bahasa adalah suatu sistem lambang yang memungkinkan orang berbagi makna. Dalam komunikasi verbal, lambang bahasa yang dipergunakan adalah bahasa verbal entah lisan, tertulis pada kertas, ataupun elektronik. Bahasa memiliki banyak fungsi, namun sekurang-kurangnya ada tiga fungsi yang erat hubungannya dalam menciptakan komunikasi yang efektif.

Ketiga fungsi yaitu untuk mempelajari tentang dunia sekeliling kita, untuk membina hubungan yang baik di antara sesama manusia, dan untuk menciptakan ikatan-ikatan dalam kehidupan manusia. Menurut para ahli ada tiga teori yang membicarakan sehingga seseorang bisa memiliki kemampuan berbahasa. Teori pertama disebut operant conditioning yang dikembangkan oleh seorang ahli psikologi behavioristik yang bernama B. F. Skinner (1957). Teori ini menekankan unsur rangsangan (stimulus) dan tanggapan (response) atau lebih dikenal dengan istilah S-R. Teori kedua ialah teori kognitif yang dikembangkan oleh Noam Chomsky. Menurutnya kemampuan berbahasa yang ada pada manusia adalah pembawaan biologis yang dibawa dari lahir. Teori ketiga disebut mediating theory atau teori penengah. Dikembangkan oleh Charles Osgood. Teori ini 
menekankan bahwa manusia dalam mengembangkan kemampuannya berbahasa, tidak saja bereaksi terhadap rangsangan yang diterima dari luar, tetapi juga dipengaruhi oleh proses internal yang terjadi dalam dirinya.

Selanjutnya kata merupakan inti lambang terkecil dalam bahasa. Kata adalah lambang yang melambangkan atau mewakili sesuatu hal, entah orang, barang, kejadian, atau keadaan. Yang kedua Komunikasi nonverbal merupakan penyampaian pesan tanpa kata-kata dan komunikasi nonverbal memberikan arti pada komunikasi verbal. Komunikasi nonverbal adalah penciptaan dan pertukaran pesan dengan tidak menggunakan kata-kata, komunikasi ini menggunakan gerakan tubuh, sikap tubuh, intonasi nada.

Menurut Sobur (2009:16), komunikasi nonverbal merupakan komunikasi tanpa bahasa atau komunikasi tanpa kata, maka tanda nonverbal berarti tanda dengan menggunakan sedikit bahasa atau sedikit kata. Komunikasi nonverbal sering dijumpai dalam dunia olahraga, misalnya tanda yang ditimbulkan peluit, atau pun tanda-tanda yang ditujukan oleh pelatih untuk memanggil atletnya. Gerakan tangan seperti acungan jempol ke arah atas (baik) atau ke arah bawah (tidak baik), ataupun gerakan-gerakan anggota badan yang lain juga termasuk komunikasi verbal dalam dunia olahraga. Komunikasi verbal dan nonverbal susah dibedakan dalam kehidupan sehari-hari. Pengaruh yang ditimbulkan dari masing-masing komunikasi tersebut sangat berhubungan. Kata yang diucapkan seorang pelatih tentu saja banyak menimbulkan banyak arti, dari nada menyampaikan, ekspresi wajah, gerakan badan, tatapan wajah dan lain sebagainya.

Ciri-ciri komunikasi nonverbal melalu ekspresi wajah, kontak mata sangat penting dalam berkomunikasi, sentuhan bersifat spontan, postur tubuh dan gaya berjalan, cara orang berjalan, duduk berdiri dan bergerak melihatkan ekspresi dirinya, dan suara merupakan suatu ungkapan perasaan dan pikiran seseorang yang dapat dijadikan komunikasi, serta gerak Isyarat adalah dapat mempertegas pembicaraan.

Menurut Reynolds (2002:1-2), faktor- faktor yang mempengaruhi komunikasi terbentuk beberapa faktor yang dapat mempengaruhi komunikasi antara pemberi pesan dengan penerima pesan sehingga pesan dapat tersampaikan sesuai dengan yang diharapkan. Ada empat faktor yang mempengaruhi, yaitu content, colloboration, creativity dan critical thinking. Content (messages of communicate) adalah kemampuan berkomunikasi yang baik terkait erat dengan kemampuan menciptakan pesan-pesannya. Collaboration merupakan aktivitas terkoordinasi dan sinkron yang merupakan hasil dari upaya terusmenerus untuk membangun dan mempertahankan konsepsi bersama tentang sebuah masalah. Creativity adalah interaksi antara kemampuan, proses, dan lingkungan dimana individu atau kelompok menghasilkan produk yang jelas, baik yang baru maupun berguna seperti yang didefinisikan dalam konteks sosial. 
Critical Thinking adalah pemikiran yang tidak kritis, dan bahwa untuk membuat keputusan yang lebih baik, refleksi diri sangat penting. Hubungan komunikasi akan terjalin manakala tercipta kondisi komunikasi yang terbuka, empati, positiveness, suportif dan setara antar berbagai pelaku komunikasi (Sudiansyah, 2017: 146).

Pada proses komunikasi, kunci kesuksesan dalam membina hubungan adalah kepiawaian dalam melakukan komunikasi intrapersonal baik pada diri pelatih maupun pada diri atlet. Komunikasi intrapersonal didahului proses sensasi, persepsi, memori dan berfikir. Proses komunikasi ini merupakan kunci dalam pendewasaan kepribadian dan kontemplasi dalam membina hubungan sosial sehingga lebih dewasa dan membangun mentalitas yang kuat (Masmuh, 2008: 91-92). Komunikasi intrapersonal merupakan keterlibatan internal secara aktif dari individu dalam pemrosesan simbolik dari pesan-pesan. Seorang individu menjadi pengirim sekaligus penerima pesan, memberikan umpan balik bagi dirinya sendiri dalam proses internal yang berkelanjutan (Sibarani, 2016).

Dalam hubungan antara pelatih dan atlet, empat faktor di atas juga ikut memengaruhi. Begitu pula dalam olahraga bulutangkis. Menurut Alhusin (2007: 30-43), atlet bertanding dikatakan berhasil bila atlet dalam melakukan kegiatan berlangsung secara intensif dan optimal sehingga menimbulkan pengaruh tingkah laku yang bersifat tetap. Perubahan tingkah laku sebagai akibat bertanding dipengaruhi banyak faktor. Dari faktor-faktor yang mempengaruhinya secara garis besar dibedakan menjadi dua yaitu faktor internal (dari dalam) diri dan faktor eksternal (dari luar) diri. Dari pembicaraan mengenai faktor-faktor yang mempengaruhi tidak hanya ditekankan pada faktor internal saja melainkan juga faktor eksternal.

Faktor internal menyangkut faktor jasmaniah, psikologis dan kelelahan. Faktor internal yang relevan dengan persoalan adalah faktor psikologis, sehingga faktor psikologis dijadikan tinjauan khususnya dalam faktor internal. Sedangkan faktor eksternal menyangkut faktor keluarga, sekolah, dan masyarakat. Keseluruhan faktor yang berpengaruh terhadap belajar mempunyai andil yang sama besar dalam memberikan dasar dan kemudahan dalam pencapaian tujuan yang optimal. Faktor psikologis yang termasuk didalamnya adalah intelegensi, perhatian, minat, bakat, motivasi, kematangan, kesiapan dan lainnya yang mempunyai peran penting. Selain itiu berbagai faktor psikologis tersebut komunikasi merupakan hal yang penting dan menunjang keberhasilan atlet saat bertanding.

Prestasi merupakan salah satu unsur yang penting dalam kegiatan pelatihan. Prestasi dapat dijadikan sebagai pendorong atau penggerak saat bertanding maka akan timbul komunikasi dengan sendirinya dan menimbulkan keinginan untuk lebih lagi meraih prestasi. Sukses dalam bertanding akan membangkitkan dan meningkatkan komunikasi dengan baik. Masalah 
komunikasi bukan soal memberikan komunikasi tetapi mengatur kondisi belajar. Komunikasi merupakan hal yang dibutuhkan saat bertanding. Semakin tepat komunikasi yang diberikan maka kegiatan akan semakin berhasil. Berdasarkan uraian diatas, hipotesis dalam penelitian ini yaitu: diduga terdapat hubungan yang signifikan antara komunikasi terhadap prestasi atlet bulutangkis di SMP 116 RAGUNAN pada Kejuaraan Djarum Sirnas tahun 2017.

Ada empat dimensi dalam penelitian ini yaitu: Content (messages of communicate), Collaboration, Critical thinking, dan Creativity. Dimensi content, memiliki tiga indikator yaitu berbagi pemikiran tentang ide, terbuka, dan solusi. Dimensi collaboration memiliki dua indikator yaitu bekerja sama untuk mencapai tujuan, dan menempatkan bakat dan keahlian. Dimensi critical thinking terdiri dari dua indikator yaitu melihat masalah dengan cara baru, dan menghubungkan pembelajaran melalui subjek. Dimensi creativity memiliki satu indikator yaitu mencoba pendekatan baru untuk menyelesaikan sesuatu dengan inovasi dan penemuan. Penelitian ini meneliti pengaruh komunikasi $(\mathrm{X})$ dan pelatih dengan atlet terhadap prestasi $(\mathrm{Y})$ atlet bulutangkis smp 116 ragunan pada kejuaraan djarum sirkuit nasional tahun 2017. Berikut ini data terendah, data tertinggi, rata-rata, simpangan baku dan varians dari masing-masing variabel $\mathrm{X}$ maupun $\mathrm{Y}$ :

Tabel 1. Deskripsi Data Penelitian

\begin{tabular}{ccc} 
Variabel & Komunikasi & Prestasi \\
\hline Nilai Terendah & 66 & 4 \\
Nilai Tertinggi & 110 & 16 \\
Rata-Rata & 94,43 & 9,7 \\
Simpangan Baku & 8,27 & 3,13 \\
Varians & 68,46 & 9,80
\end{tabular}

Sumber: hasil penelitian

Sementara itu, hasil uji normalitas dengan Kolomogrov Smirnov pada variabel $X$ di dapat hasil sebesar 1,010. Nilai tersebut diatas 0.05, maka distribusi data dinyatakan memenuhi asumsi normalitas. Sementara untuk variabel $\mathrm{Y}$, pada kolom Kolomogrov di peroleh nilai sebesar 0,761. Nilai tersebut diatas 0.05, maka distribusi data dinyatakan memenuhi asumsi normalitas. Sedangkan hasil homogenitas diperoleh nilai signifikansi sebesar 0,061. Nilai signifikansi tersebut lebih besar dari 0.05 , artinya data variabel prestasi atlet bulutangkis $(\mathrm{Y})$ berdasarkan pengaruh komunikasi pelatih $(\mathrm{X})$ mempunyai varians yang sama. Dan hasil Uji kebeartian koefisien korelasi sebesar 0,566. Hasil ini menunjukan ada pengaruh antara prestasi atlet bulutangkis yang dengan komunikasi pelatih, sebesar $56,6 \%$.

Komunikasi antara pelatih dengan atlet merupakan komunikasi yang berlangsung antara dua orang atau lebih dengan begitu dapat dikatakan merupakan komunikasi antarpribadi. Komuikasi ini dapat dibedakan menjadi 
dua macam, yakni komunikasi diadik ialah proses komunikasi yang berlangsung antara dua orang dalam situasi tatap muka, sedangkan komunikasi kelompok ialah proses komunikasi yang berlangsung antara tiga orang atau lebih secara tatap muka, dimana anggota-anggotanya saling berinteraksi satu sama lainnya.

Komunikasi memiliki beberapa faktor yang dibuktikan dapat mempengaruhi prestasi atlet bulutangkis yaitu, dimensi content (message of comunicate) berdasarkan data penelitian mempunyai pengaruh yang tinggi, pada dimensi collaboration berdasarkan data penelitian komunikasi pelatih terhadap dimensi ini mempunyai pengaruh yang rendah, pada dimensi critical thinking berdasarkan data penelitian komunikasi pelatih terhadap dimensi ini memiliki pengaruh yang sedang, dan pada dimensi creativity berdasarkan data penelitian komunikasi pelatih terhadap dimensi ini memiliki pengaruh yang sedang. Dari keempat dimensi tersebut memiliki peran penting yang harus dimiliki oleh pelatih dalam memberikan pengaruh terhadap prestasi atlet bulutangkis SMP 116 Ragunan pada kejuaraan Djarum Sirkuit Nasional tahun 2017.

Berdasarkan hasil penelitian yang telah dibahas pada point-point sebelumnya dapat diketahui bahwa pengaruh komunikasi pelatih terhadap prestasi atlet bulutangkis SMP 116 Ragunan pada kejuaraan Djarum Sirkuit Nasional tahun 2017 didapatkan hasil sebesar 56,6\%. Berdasarkan hasil tersebut pengaruh komunikasi pelatih dikatakan memiliki pengaruh yang signifikan terhadap prestasi atlet bulutangkis smp 116 ragunan pada kejuaraan djarum sirkuit nasionl tahun 2017. Dengan begitu teori yang menyatakan bahwa komunikasi memiliki peran penting kepada pelatih untuk dapat mempengaruhi prestasi atlet bulutangkis yang diharapkan dari setiap atlet bulutangkis sesuai dengan penelitian yang ada dilapangan.

\section{PENUTUP}

Berdasarkan hasil penelitian, maka dapat ditarik beberapa kesimpulan yaitu: Komunikasi pelatih berhubungan erat (kuat) dengan prestasi atlet bulutangkis SMP 116 Ragunan pada kejuaraan Djarum Sirkuit Nasional tahun 2017 sebesar 56,6\%. Meski demikian terdapat sekitar 43,4\% yang terkait dengan aspek lainnya diluar komunikasi. Kemampuan komunikasi pelatih dalam membangun atau menciptakan pesan-pesan komunikasi (content) yang bersifat berbagi pemikiran, terbuka, dan mencakup solusi untuk kepentingan bersama (atlet dengan pelatih) memiliki hubungan yang lebih kuat dibanding 3 dimensi lainnya, yaitu dimensi collaboration, dimensi critical thinking, dan dimensi creativity.

Untuk penelitian sejenis selanjutnya, maka peneliti menyarankan beberapa hal sebagai berikut: dalam mengembangkan prestasi atlet bulutangkis diperlukan keahlian pelatihan-pelatihan yang sesuai dalam mengembangkan kemampuan berkomunikasi pelatih terutama terlebih fokusnya menguasai keahlian collaboration, critical thinking, dan creativity. Mendalami aspek komunikasi nonverbal 
antara pelatih dengan atlet yang tidak diteliti dalam penelitian ini, kemudian perlu dipahami lebih dalam dimensi lainnya, selain 4 dimensi yang sudah diteliti dalam penelitian ini.

\section{DAFTAR PUSTAKA}

Alhusin, S. (2007). Gemar Bermain Bulutangkis. Surakarta: CV Seti Aji

Charles, P., \& Nurjanah, S. (2016). Komunikasi Interpersonal Antara Pelatih Dan Atlet Bulutangkis Dalam Meningkatkan Prestasi Pada Dinas Pemuda Dan Olahraga (Dispora) Provinsi Riau, dalam Jurnal Online Mahasiswa (JOM), 3(2).

Giandra, S.N. \& Setyawan, I. (2015). Hubungan antara Efektivitas Komunikasi Interpersonal Pelatih dengan Ketangguhan Mental Atlet. dalam Jurnal Empati, 3(4), 1-10.

Hafiar, H. (2012). Cacat dan Prestasi melalui Pengalaman Komunikasi Atlet Penyandang Cacat, dalam Jurnal Indonesian Journal of Dialectics, 2(1).

Jatmikowati, T.E. (2018). Efektifitas Komunikasi Orang Tua terhadap Kepribadian Intrapersonal Anak, dalam Jurnal Pedagogi, 4(2).

Kurniasari, S.S. (2014). Proses Komunikasi Interpersonal Antara Pelatih yang Merangkap sebagai Atlet Panjat Tebing yang Dilatihnya. dalam Jurnal eKomunikasi, 2(2), 1-10.

Masmuh, A. (2008). Pendewasaan Kepribadian melalui Komunikasi Intrapersonal, dalam Jurnal Bestari, 39(2), 86-93.

Muhammad, A. (2011) Komunikasi Organisasi. Jakarta: PT Bumi Aksara.

Oktafiranda, N.D., Pelana., \& Marani, I.N. (2015). Efektifitas Komunikasi antara

Pelatih dan Atlet terhadap Prestasi Atlet Panahan Pusat Pendidikan Latihan Pelajar (PPLP) Nasional, dalam Jurnal Segar, 3(2).

Reynolds, P. H. (2002) We're Taking Teaching and Learning. Washington DC, Saputro, S.K. (2014). Proses Komunikasi Interpersonal Antara Pelatih Yang Merangkap Sebagai Atlet dengan Atlet Panjat Tebing yang Dilatihnya, dalam Jurnal e-Komunikasi, 2(2). 1-10.

Setiani, O. \& Sakti, H. (2014). Hubungan antara Efektitivitas Komunikasi Interpersonal Pelatih dan Atlet dengan Kecemasan Bertanding pada Atlet Persatuan Bulutangkis Seluruh Indonesia Semaran. dalam Jurnal Empati, 3(3), 186-195.

Sibarani, R.C. (2016). Komunikasi Intrapersonal dan Perilaku Fobia (Studi Deskriptif Kualitatif Proses Komunikasi Intrapersonal Hipnoterapi dalam Mengubah Prilaku Fobia Klien di Klinik Tranzcare Jakarta), dalam Jurnal Flow, 2(19).

Sudiansyah, A. (2017). Efektivitas Komunikasi Dakwah di Pesantren MQdalam Merubah Akhlak Santri, dalam Jurnal Communicatus: Jurnal Ilmu Komunikasi, 1(2), 151-158. 
F. Faisal, Zulham, A. Syukur, D. Safitri

Sobur, A. (2009) Semiotika komunikasi, Bandung: PT. Remaja Rosdakarya.

Torana, Y.I. (2016). Komunikasi Interpersonal Antara Ayah Dan Anak Yang Berprofesi Sebagai Atlet Bela Diri Muay Thay Dalam Menjaga Sikap Profesionalisme, dalam Jurnal e-Komunikasi, 4(2).

Widjaja, H.A.W. (2010). Komunikasi dan Hubungan Masyarakat. Jakarta: PT Bumi Aksara.

Yuniarti, T. (2011). Strategi Komunikasi Tvone dalam Penayangan Makelar Kasus Palsu, dalam Jurnal FKSB Makna, 2(2). 